\title{
DENSITAS KAMBA JAGUNG HIBRIDA PERTIWI KABUPATEN SIDENRENG RAPPANG
}

(Bulk density of pertiwi hybrid corn Sidenreng Rappang regency)

\author{
Salfiana $^{1}$ dan Rismawati ${ }^{2}$
}

1,2 Program Studi Teknologi Hasil Pertanian, Universitas Muhammadiyah Sidenreng Rappang Jln Angk. 45 No.1 A Lt. Salo Rappang - Sidrap - Sul-Sel Telp. (0421) 93308

Email: Salfiana.husain@umsrappang.ac.id

\begin{abstract}
ABSTRAK
Tujuan penelitian ini adalah melakukan pengukuran atau identifikasi secara kuantitatif terhadap densitas kamba jagung hibrida pertiwi Kabupaten Sidenreng Rappang. Penentuan densitas kamba dilakukan dengan menghitung massa biji jagung per volume yang yang ditempati termasuk ruang kosong antara bahan. Hasil perhitungan diperoleh densitas kamba jagung Hibrida Pertiwi Kabupaten Sidenreng Rappang berada pada kisaran $705-745 \mathrm{Kg} / \mathrm{m}^{3}$.
\end{abstract}

Kata Kunci: Densitas kamba; jagung; Hibrida Pertiwi; Sidenreng Rappang.

\begin{abstract}
The aim of this research was to measure or quantitatively identify the Bulk Density Of Pertiwi Hybrid Corn Sidenreng Rappang Regency. Determination of bulk density is done by calculating the mass of corn kernels per volume occupied including the empty space between the corn kernels. The results of the calculation obtained that the Bulk Density Of Pertiwi Hybrid Corn Sidenreng Rappang Regency was in the range of $705-745 \mathrm{Kg} / \mathrm{m}^{3}$.
\end{abstract}

Keywords: Bulk density; corn; pertiwi hybrid; Sidenreng Rappang

\section{PENDAHULUAN}

Jagung (Zea mays L.) adalah salah satu tanaman yang paling banyak dan relatif mudah di budidayakan dalam berbagai kondisi pertanian dan iklim. Secara global, jagung dikenal sebagai ratu serealia karena memiliki potensi hasil genetik tertinggi di antara serealia. Di Kabupaten Sidenreng Rappang jagung dibudidayakan sepanjang tahun.

Di Kabupaten Sidenreng Rappang, salah satu jenis jagung yang banyak di budidayakan adalah jagung hibrida pertiwi. Jagung tersebut mudah memiliki kesesuaian dengan penggunaan teknologi yang dirancang. (Oelviani et al., 2012) telah melakukan penelitian tersebut dengan menganalisis efektivitas penggunaan teknologi pada jagung hibrida.

Densitas kamba merupakan salah satu sifat fisik yang sangat penting untuk diketahui. Densitas kamba berperan dalam pengetahuan rendemen, pengemasan, penyimpanan serta transportasi. Pada umumnya petani belum mengoptimalkan pengetahuan teknologi (Sangamithra, 2016) yaitu tanpa mengetahui secara signifikan densitas kamba bahan. 
Penelitian betujuan untuk melakukan pengukuran atau identifikasi secara kuantitatif terhadap densitas kamba jagung hibrida pertiwi Kabupaten Sidenreng Rappang.

\section{METODE PENELITIAN}

Penelitian densitas kamba jagung Hibrida Pertiwi Kabupaten Sidenreng Rappang dilaksanakan pada Bulan September 2021 di Program Studi Teknologi Hasil Pertanian, Fakultas Sains dan Teknologi, Universitas Muhammadiyah Sidenreng Rappang, Kabupaten Sidenreng Rappang.

Alat yang digunakan pada penelitian ini adalah:

1. Wadah plastik

2. Gelas kimia $1000 \mathrm{ml}$

3. Timbangan analitik

Bahan yang digunakan pada penelitian ini adalah:

1. Sampel jagung hibrida pertiwi Kabupaten Sidenreng Rappang

2. Plastik klip

Prosedur pada penelitian ini adalah:

1. Pengambilan Sampel

2. Analisis densitas kamba

a. Gelas kimia diletakkan di atas timbangan dengan posisi awal $0 \mathrm{~g}$.

b. Memasukkan biji jagung pada gelas kimia $1000 \mathrm{ml}$ c. Gelas kimia digoyang-goyangkan hingga tidak ada lagi rongga ketika sampel ditepatkan menjadi $1000 \mathrm{ml}$.

d. Dilihat angka yang ada di timbangan.

e. Penentuan densitas kamba dihitung dengan:

$$
\begin{gathered}
\rho=\frac{m}{v} \ldots \ldots . .1 \\
\rho=\operatorname{Densitas} \operatorname{Kamba}\left(\mathrm{Kg} / \mathrm{m}^{3}\right) \\
\mathrm{m}=\text { Massa Biji Jagung }(\mathrm{Kg}) \\
\mathrm{v}=\operatorname{Volume} \operatorname{wadah}\left(\mathrm{m}^{3}\right)
\end{gathered}
$$

\section{HASIL DAN PEMBAHASAN}

Hasil dari penelitian densitas kamba jagung Hibrida Pertiwi Kabupaten Sidenreng Rappang adalah sebagai berikut:

Tabel 1. Spesifikasi hasil penelitian densitas kamba jagung hibrida pertiwi

\begin{tabular}{ccccc}
\hline $\begin{array}{c}\text { N } \\
\text { o }\end{array}$ & $\begin{array}{c}\text { Kode } \\
\text { Sampel }\end{array}$ & $\begin{array}{c}\text { Massa } \\
(\mathbf{K g})\end{array}$ & $\begin{array}{c}\text { Volume } \\
\left(\mathbf{m}^{\mathbf{3}}\right)\end{array}$ & $\begin{array}{c}\text { Densitas } \\
\text { Kamba } \\
\left(\mathbf{K g} / \mathbf{m}^{\mathbf{3}}\right)\end{array}$ \\
\hline 1. & 17783 & 0,745 & 0,001 & 745 \\
2. & 82995 & 0,707 & 0,001 & 707 \\
3. & 96754 & 0,714 & 0,001 & 714 \\
4. & 40950 & 0,705 & 0,001 & 705 \\
5. & 54463 & 0,708 & 0,001 & 708 \\
\hline
\end{tabular}

Sumber: Data Sekunder Densitas Kamba Jagung Hibrida Pertiwi di Kabupaten Sidenreng Rappang, 2021. 
Densitas kamba jagung Hibrida Pertiwi Kabupaten Sidenreng Rappang berada pada kisaran $705-745 \mathrm{Kg} / \mathrm{m}^{3}$. Hal ini tidak jauh berbeda dengan teori yang dikemukakan (Muchtadi, 2010) bahwa umumnya sifat fisik seralia berupa Jagung memiliki densitas kamba $745 \mathrm{Kg} / \mathrm{m}^{3}$.

Beberapa sampel yang memiliki densitas kamba yang lebih rendah dari teori tersebut kemungkinan disebabkan oleh penggunaan benih jagung varietas hibrida pertiwi yang berulang. Hal ini sama yang ditemukan (Taufik, 2015) dilapangan, dimana hasil temuan beliau, mendapatkan sebagian petani masih menggunakan benih varietas hibrida pertiwi dari pertanaman sebelumnya.

Namun, dari penelitian ini diperoleh nilai densitas kamba yang cukup baik. Karakteristik jagung hibrida pertiwi memang memiliki kualitas yang baik. Hasil penelitian (Maintang, 2018) menyimpulkan tinggi tanaman dan diameter batang merupakan karakter atau penciri jagung hibrida yang menghasilkan bobot tongkol kupasan basah, panjang tongkol, jumlah tongkol panen, jumlah biji / baris, dan bobot 1.000 biji baik sesuai dengan mutu.

\section{KESIMPULAN}

Kesimpulan pada penelitian adalah Densitas kamba jagung Hibrida Pertiwi Kabupaten Sidenreng Rappang berada pada kisaran $705-745 \mathrm{Kg} / \mathrm{m}^{3}$.

\section{DAFTAR PUSTAKA}

Maintang, R. E. 2018. Penampilan Karakter beberapa Genotipe Jagung Hibrida. Informatika Pertanian, 4762.

Muchtadi, T. S. 2010. Ilmu Pengetahuan Bahan Pangan. Bandung: Alfabeta.

Oelviani et al., S. D. 2012. Corn-seed technology: a study of a new technology introduce to farmer using importance performance analisys. E3S Web of Coferences .

Sangamithra, S. G. 2016. Moisture dependent physical properties of maize kernels. International Food Research Journal , 109-115.

Taufik, M. M. 2015. Kelayakan Usahatani Jagung di Sulawesi Selatan. Jurnal Pengkajian dan Pengembangan Teknologi Pertanian, 67-80. 